\title{
The Distorted Image of Prophet Muhammad in Percy's Mahomet and His Heaven (1601)
}

\author{
Dr. Fahd Mohammed Taleb Al-Olaqi \\ Department of English \& Translation \\ Faculty of Science \& Arts - Khulais \\ University of Jeddah, Jeddah \\ Kingdom of Saudi Arabia
}

\begin{abstract}
The article critiques the portrayal image of Prophet Muhammad in William Percy's Mahomet and His Heaven (1601) (Note: 1). The play is marked with anti-Mahomet prejudice expressed in willful attempts to devalue Prophet Muhammad in order to avert the English public from Islam. The story of Haroth and Maroth in the Noble Qur'àn is misused to vilify Islam and its Prophet. Percy pinpoints some unscrupulous and offensive characterization to Prophet Muhammad to blame him for the establishment of a competitive Islamic world to Christendom. Thus, Percy exemplifies the typical Elizabethan sense of the delight in defaming Islam and Prophet Muhammad. Like Percy, some Elizabethan dramatists attacked the religious symbols of the Ottoman Islamic World to defend European Christian values. The Elizabethan hostility and antisentiment towards the Ottoman Empire was sceptical to the Islamic multicultural integration. The scenes of Medieval Christian polemical accounts are reproduced in dealing with Islamic theology, fallacy, prophecy, and characterization.
\end{abstract}

Keywords. Percy, Mahomet, Heaven, Prophet Muhammad, Islam, the Holy Qur'ān, Haroth and Maroth.

\section{INTRODUCTION}

William Percy's Mahomet and His Heaven (1601) is known by alternative titles too: Arabia Sitiens, A Dreame of a Dry Yeare, Epimenide, Grand Empress of the Deserts of Arabia, A Dream of a Dry Summer, or The Weather-Woman (1601) (Note: 2). The work is an Islamic colour in Elizabethan England's literature and art. It sorts Islam and Muslims in a predominantly domestic discourse for the British readership. It is the first in Elizabethan play to present the figure of Prophet Muhammad on the stage. This comic play is set in 'Medina Talnabi' - the city of the Prophet in Hejaz, Western land of 'Arabia Deserta.' The dramatic setting of the second sacred city of Islam shows a break from the real locale to the deep heart of the Islamic World. Percy's play falls back on and furthers the wilful misrepresentation of Islam found in the fictional and historiographical writings from the sixteenth and seventeenth centuries. For instance, Percy neglects the fact that Islam is a monotheist religion and portrays it as a pagan faith. In particular, the alleged Islamic "belief in Mohammed as a god, is frequently repeated throughout the period of the Crusades" (Munro 1931, p. 332). He levels blatant accusations against Islam. It seems that Percy indents to make the play a masterpiece of creative writing, but it turns to a misinformation about Prophet Muhammad (Peace Be Upon Him) in representing him wrongly as an evil individual, a big liar, and lustful in nature. These accusations are totally disapproved by Western scholars. The play includes numerous derogatory accounts that twist the facts of the genuine life of the Messenger of God as shown in qualified historical volumes as well as in the Noble Qur'ān of Islam. 
The play has a critical significance in the ideological advantage of the Elizabethan Orientalist paradigm. It also interacts with the early Elizabethan controversial mythologies of Islam and Prophet Muhammad. It starts with the Prophet's decree on a corrupt people of Arabia, a place he desires to punish with a divine famine. Angels and spirits are sent to examine, but in the last part of the play they bring only deception to Mahomet who is currently unconvinced with the heavenly regulations. In Act Five, Epimenide, the Queen of the Arabian Desert, and the object of the play's several sensual hunts, has seduced the figure of the Prophet himself. Like many of his contemporaries, Percy links Arabia with luxury and sexual licence. By employing Islamic elements, he finally employs those notions to distort the Islamic faith in heaven. The play has borrowed a great Medieval accounts in order to scorn Islam and Prophet Muhammad on a more secular stage of London. Percy's play establishes the divinity of Mahomet who is clearly dominant and in a negative vein above the angels and God. To carve the image of a semi-god of Mahomet or as an arch conjurer of the devil, the dramatist institutes a straight triangle similarity between Mahomet and Christ, and between Mahomet and the Antichrist. Percy's crucial purpose is to portray visibly Mahomet as the mirror-image of the Islamic Saviour. The misrepresentations and anti-Mahomet prejudices of English playwrights towards Islam in Elizabethan Drama survived well into modern times. The sixteenth century Christians had nothing positive to say about Islamdom or Muslims (Reeves 2000, p.23). Samuel Chew remarks that Elizabethan armchair historians could not avoid prejudice in their accounts like Knolles in General History of the Turke (1603), for their purpose was largely propagandist. Knolles describes Mahomet as an image of Satan with ancient heretics and "born in an unhappy hour", and his "gross and blasphemous Doctrines [Islam]" (Chew 1937, p.115). Nowadays, Western scholars examine the Elizabethan interest in Islam. For instance, Katie Sisneros finds out that the 'English interest in the Ottoman Empire was primarily in their religion' (Sisneros, 2010, p.5); Nabil Matar refers to the English interest as "perhaps the climax of curiosity about things Islamic" (Matar 1991, p. 67); and Pnina Werbner thinks that the English interest in representing Muslims in Renaissance texts is part of the impact of the early modern conceptions of ethical diversity and multiculturalism (Werbner \& Modood 1997, pp. 4-5).

The central effect of the Elizabethan distortion of Islam is that the instant aversion to Islam reproduces different types of prejudice against Islam, Prophet Muhammad and Muslims. The identification of Islam as a heresy or false religion, propagated by a false prophet and inspired by the devil, contributed to the connotation of the figure of any Muslim Turk or Moor as a false and treacherous person. With the advent of Renaissance, the Christian-Muslim interaction increased due to overseas businesses (Matar 1998, p.14). On the other hand, the increased presence of Muslims on London stage is conspicuous in representing the Elizabethan reactions to the Ottoman Turks, Moors, Arabs, and Islamic religious symbols such as Prophet Muhammad and the Qur'ān in many dramatic scenes. Moreover, some plays include the names of Ottoman sultans such as Percy's Mahomet, Kyd's Soliman and Perseda (1588), Peele's Turkish Mahomet (1595) and Selimus (1594), Goffe's Bajazet the Second (1618) and Amurath the First (1619), etc. Louis Wann notes that there are at least forty-seven Oriental plays performed on the Elizabethan stage (Wann 1915, pp.168-69). Fahd Al-Olaqi remarks that Orientalism is a form of Elizabethan hegemony particularly with reference to Elizabethan Turkish style of costume, desires, repressions, investments, and representations (Al-Olaqi, 2013, p. 52). William Percy's Mahomet and His Heaven, appears to have been an attempt to explore the English ideological stance to the religion of the Turks and Moor in the seventeenth century. It is the only existing play that has frequently negative allusions to the Qur'àn and the Prophet, though some plays refer to a few Qur'ānic verses such as Christopher Marlowe's Tamburlaine (1588) and Robert Wilson's Three Ladies of London (1581); and the brazen head of Muhammad in Robert Greene's Alphonsus of Arragon (1591) and in Robert Daborne's A Christian Turned Turk (1609) (Note: 3). Because of these prejudiced views of Prophet 
Muhammad, the depiction of the lustful and wicked Muslim Turk or Moor gives frequently the impression of an evil Islamic culture on the English stage. Vitkus quotes Jack D' Amico's comments on demonizing Islam in an offensive way:

The problem of containing Islam, politically and intellectually, was made more difficult by those respects in which Islamic culture was actually superior. [...] A more potent and seductive foe, Islam, had to be represented as a dangerous distortion of the true Church, a parody of civilization, its Mohammed a false prophet, its Jihad a perversion of the Crusade, its book, the Koran, a collection of errors and lies that mocked the Bible (Vitkus 2000, p. 15).

The image of the Messenger Muhammad has been distorted to spread fake information, hostility and religious propaganda. English writers spread fear of Prophet Muhammad and Muslims as they would wreak havoc on England. Therefore, the portrait of Islam and Prophet Muhammad has always been biased in the West. This distortion of Islam is central in the tenets of Medieval anti-Islamic scholasticism. The Western Medieval and Renaissance library has several books about Islam and Prophet Muhammad such as John Mandeville's The Travels of Sir John Mandeville (1371), Ranulph Higden, Polychronycon (1527), Naumann's Riccoldo's Contra Legem Sarracenorum (1542), Robert Ketton's Lex Mahumet pseudoprophete (Law of Muhammad the False Prophet) or the Koran (1543), Nicolas de Nicolay's Navigations into Turkie (1568), Sebastian Munster's Cosmographia (1572), Thomas Newton's translation of Celio Augustino Curione's Noteable History of the Saracens (1575), John Foxe's History and Tyranny of the Turks (1570), George Whetstone's the English Myrror (1586), George Abbot's A Brief description of the whole world (1599), Leo Africanus' A Geographical History of Africa (1600), Richard Knolles's General History of the Turks (1603), Robert Carr's The Mahumetane or Turkish Historie (1600), Joseph Wybame's The New Age of Old Names (1609), Giles Fletcher's The Policy of the Turkish Empire (1597), William Biddulph's The Travels of certaine Englishmen (1609), George Sandys's A Relation of a Journey begun Anno Domini 1610 (London, 1615), William Bedwell's Mohammed's Imposture (1615), Peter Hevlyn's Mikrokosmos (1625), Walter Raleigh's The life and death of Mahomet the conquest of Spaine (1637), etc. Daniel Vitkus suggests that the perception of Islam as a threat can explain the ongoing process of the demonization of Muslims despite an increasing availability of new and accurate information on the Islamic world (Vitkus 1999, p. 208). On the other hand, part of the Western Europeans' attraction to Islamic World and the Turks and Moors lay in the latter's generosity, the multiethnic cities, and a sentiment that their overwhelming supremacy is raised up by God (MacLean and Matar 2010, pp.90-112). The Elizabethan English was scared of religious and cultural integration upon growing communication with Muslims. Robert Daborne's A Christian Turn'd Turke (1609) and Phillip Massinger's The Renegado (1623) emphasize the imminent threat of the increasing religious conversion to Islam.

Percy's play displays a contrived hostility and prejudice against the increased Elizabethan fascination for Islam and Muslim Turks. Christendom was always losing converts to Islam while Islam was constantly being vilified in controversial texts. Therefore, the polemical distortion of Islam and its Prophet represents unreal assumptions. For instance, the claim that the synthetic nature of Prophet Muhammad is of mixing elements of Christian and Jewish mysticism, is to substantiate his personal predilections (Tolan 2002, pp.155-65). This idea is echoed in several texts such as Robert Carr's notes in The Mahumetane or Turkish Historie that the English believe God will judge the Muslims: "the Mahumetans, who [,] misled by the lyes of that wicked Imposter, and following his damned positions, diuerting from the eternall path of saluation, are carryed headlong in theyr misbeliefe to hell torments, and euerlasting 
damnation...."(Carr 1600, p. 113); in Knolles, "the false Prophet Mahomet" had come to destroy mankind and he had not only "desolat[ed]" the Christian Church but had created a vast population of Muslims who would all be damned, "millions of soules cast headlong into eternall destruction"'(Knolles 1603, .4); and in John Foxe's History and Tyranny of the Turks (1570), the first English history of the Turks, his hostility to Islam and the Turks overrides any attention to the human or political dimensions of Ottoman history (McJannet 2006, p.58).

\section{WESTERN POLEMICS}

The destructive Western portrayal of Islam is advanced under the excuses of defending Christianity. Medieval Christians saw the Islamic world as their demonic Other, but as English experience with Mediterranean traffic increased, statesmen and merchants alike began to rethink the old stereotype more pragmatically (Bak 1996, pp.201-5 \& Vitkus 1997, pp.24-44). As the tremendously destructive view of the Oriental Turk as the Other triumphed in the commencement of Elizabethan Age, the conflict between the so-called English civility and the Ottoman brutality facilitated defining England as a nation, which was in exploration of a public ground in religious conviction and politics. England's league and cooperation with traditional Turkish and Moorish 'infidels' of the Christendom was controversial among the Britons. Percy's play reacts anxiously to the consequences of increasing cultural encounters between England and the Islamic East. Therefore, Percy's selection of the figure of Prophet Muhammad could endure a range of interpretations that reproduced and exposed Western religious desires, concerns, and agendas in his play. The subsequent depictions created by the dramatist misrepresented Prophet Muhammad as an agent of the Antichrist. He was wrongly represented as an impostor, anti-Christ and religious fanatic. In fact, such polemical European writings indicted the Prophet as an ambitious man involved in the creation of an innovative religion to encounter Christianity (Kidwai 1997, p.2).

The Western depictions of Prophet Muhammad were attempts to disfigure his image among the Europeans. For centuries, Prophet Muhammad has been at the center of European discourse on Islam. John Tolan questions the European perception to him as an impostor rather than a lawgiver. In Christian mythology, anti-Islamic propagandists claim that Mohammed is a great seducer (Tolan 2000, p.131). From the Medieval era to the Renaissance, European writings usually defined Islam as an immoral religion of sensuality. A long-lasting Christian tradition of anti-Islamic polemic criticized Islam as a structure established on fraud, lust, and violence. For instance, in a sermon, Edward Kellett's offences on Islam contain a vilified description of Prophet Muhammad as an impostor, a juggler, a Mount-bank, a bestial people-pleaser, a misbeliever, etc (Vitkus 1997, p 152).

Percy's play shows the Elizabethan suspicion on the subsequent changes over the AngloOttoman relations that turn from endangerment and enmity into communal and cultural harmony. The play did not seem an interesting one to the Elizabethan audience in particular or the English in general. It contains repeated polemical accounts about the teachings and the biography of the Messenger Muhammad. The play is allegedly based upon the Qur'ān and it is a unique play in its constant dramatic depiction of the Prophet. Percy focuses basically on the nature of anti-Islamic propaganda. For Percy the Qur'ān is a subject of study, a silk-bound and bejewelled indicator of status, a means to effect religious reconciliation (Dimmock 2006, p.2). Percy personifies Prophet Muhammad in a potentially sacrilegious act as in the Medieval tradition (Dimmock 2006, p.2). Like Percy, other Elizabethan dramatists were too vehemently opposed to Islam. Matar finds that Elizabethan anti-Islamic and anti-Muhammad rhetoric are to mock Moorish and Turkish Muslims. While the Ottoman Empire was following and upholding the law of the Holy Qur'ân, it was "a higher civilization than Christendom" (Matar 1998, p.15). Images of the Turks and Prophet Muhammad are most frequently propagated in 
the Elizabethan drama. For instance, Percy's refutations of Islam establish a false impression that is intended to mislead, especially propaganda issued by a government organization to a rival power or the media. To this argument, Percy makes a compatible portrayal of Islam as mere superstition or heresy, but it comes closer to England in exploring how the competition for command by various divisions (secular and religious) weakens the people's confidence in their government. Jack D'Amico observes that the problem of containing Islam, politically and intellectually, was made more difficult to understand Muslims in the West in which Islamic culture was actually superior (D'Amico 1991, pp.75-76). In the Renaissance period, while the power of the Ottoman Empire was in weakening, the English advent of identity was still in danger of the multicultural differences of the Turks (Akalin 2001, p.289). Burton claims that the English depiction of Islam was due to commercial, political, and social factors. The abundant descriptions of Islam created by English writers "ranged from censorious to the laudatory" (Burton 2009, p.12). For Burton, Christians' conversion to Islam was synonymous to "an act of infidelity and treason; to turn Muslim was to turn from Christian virtue (Burton 2009, p.16). Unlike Burton, in Giles Fletcher's The Policy of the Turkish Empire (1597) the account includes a description of the ambitious Muhammad as an 'atheist' (Fletcher 1597, p. 2 \& Biddulph 1609, p.92).

Islam exhibits an indigenous society which naturally secures itself from any new community. However, there is evidence from early modern English travel accounts of Britons accepting Muslim hospitality. Unlike this positive account, Biddulph travelled to Aleppo with presuppositions, and claims that Islam is a "monstrous and most devilish religion". Some additional material from Higden's Polychronicon includes the naming of Muhammad as a 'nygromancer' (Higden 1527, sig. J2v). In this version it is stated, in the speech of Anima from Passus XVII, that Muhammad himself was a renegade Christian: "Me fynde wel f)at Macometh was a man ycristened/And a cardinal of court, a gret clerk withalle,/And persuade to haue be pope, prince of holy chirche" (Piers Plowman 11.165-8) (Pearsall 1978, p. 23). Here Muhammad is shown to be a high-ranking churchman, with ambitions to be the pope. The account relates how he failed and escaped to Syria when his ambition in Rome was not realised: 'Forthy souhte he into Surie and sotiled how he myhte/ Be maister ouer alle tho men' (11.169-170). Although the idea of Muhammad as an ambitious man, indeed a man monomanically fixated on power and domination, and also as a person employing religion to further his political goals, continued in the early modem texts, the depiction of Muhammad himself as a renegade Christian did not survive since some other details of this account were applied elsewhere to the story of Sergius. In 1572, the translation of Sebastian Munster's Cosmographia provided an echo of the Medieval idea of Muhammad as a Christian by claiming that Muhammad 'flattered ye Christians in this that he was baptized of Sergius,' a charge which is repeated verbatim by Meredith Hanmer in his Baptizing of a Turke (1586). This description contained in Whetstone's the English Myrror (1586) which appears to be the basis for Alexander Ross's Alcoran of Mahomet (1649), where he states how Monk Sergius taught Mahomet the heresy of Islam in the Byzantine Empire (Whetstone 1586, pp.ii-iii).

The early modern representation of the figure of 'Mahomet' is extensively branded in a ridiculous sort of vilification, falsification and deception which retains the Christian conceptions of Islam. Matthew Dimmock states that an extensive range of Elizabethan literary, historical and visual sources endlessly recycled the profile of Mahomet as a fabricated figure and his biography as bogus, but it established a challenge to writers to imagine him in storytelling and offered new perspectives on their sense of the Islamic Oriental World, its geography and religions (Dimmock 2013, p.53). These hostile and hatred attitudes have been in the service of the defending stance of the Western civilization, viz-a-vis Islam. For example, the Elizabethan misrepresentation of Prophet Muhammad in the image of a brazen head is to 
vilify and attach idolatry to the Prophet in front of the English public. On the Elizabethan stage the figure of Prophet Mohammed speaks from within the brazen head and prophesies: 'Mahomets Poo' has been seen as an allusion to the brazen head of Mahomet, which offers Delphic advice in Alphonsus. Greene does not seem indebted to a particular authority for his plot and introduces many unhistorical situations and characters as well as magical and romance motifs within a Western mythological framework. The same idea is also in Fulke Greville, "Whence Mahomet himself an idol makes, /And draws mankind to Mecha for his sake " (Greville 1870, p.518).

Dimmock finds that Percy admires the myth of 'Haroth and Maroth' in the translation of Peter of Cluny (Dimmock 2006, p.3). In 1143, 'the Venerable' Peter of Cluny introduced the first translation of the Qur'ān in Latin, and Robert of Ketton entitled the translation as Lex Mahumet pseudoprophete (1143) which was reproduced in the 1543 Qur'ān (Al-Olaqi 2010, p.52). It seems apparent that on the basis of the negative representation of Islam in the works of some Orientalists there is a tangible impact of previous images tracing back to the Medieval sense of Islam associated with heresy. Bennett remarks that Medieval Europe considered Prophet Muhammad as "the Devil's son, the Devil incarnate, a false prophet and a charlatan" (Bennett 1992, pp.6-7). Percy's play demonstrates his false sense of the monstrosity of Islam. This monstrosity does not exist in Islamic teachings. Percy proposes to display the figure of Mahomet as less qualified of divine work than an angel and he seems to inspired by a devil. Percy describes Mahomet as 'Mahound' which is a Medieval synonym of the Devil. In projecting Percy's Mahomet, the depiction of 'Mahound' sits as a mediator in the Islamic heaven, which represents him as a god encircled by his angels (I.i.10). It is a suggestion that Percy's dramatic legend about the Prophet imitates the Christian mythology as it responses to the Christian Medieval polemics in depicting Muhammad as a God.

\section{PERCY'S MAHOMET}

Percy's Mahomet is represented to spread hate and hostility. The play works from some dirty lies about Prophet Muhammad to prevent better understanding of Islam. For example, the alchemy spell of flying up to Mahomet's heaven is a lie that is considerably tossed around in the play. It is made to show that Islam is based on superstitions and fables. As the play progresses the triviality of the figure of Mahomet and the Muslim characters makes the audience let out guffaws. This comic play deliberately shows the religion of Prophet Muhammad as incompatible with English values. In Renaissance Drama, the externals of Oriental life are portrayed with fair accuracy, but religious and cultural allusions are frequently misinterpreted and distorted (Oueijan 1966, p.15). Norman Daniel observes that the ignorance of the true nature of Islam is not the only reason for the hostility between the Islamic East and the Christian West, since there is not enough firsthand information to dispel much of the ignorance (Daniel 1960, p.45). Daniel argues that the predominant European opinion is established on misunderstanding Islam as it is "essentially built upon a foundation of sexual license which as plainly contrary to the natural and the divine law" (Daniel 1958, p.152). This tradition of anti-Islamic polemic endured to present the religion of Prophet Muhammad as one based on "fraud, lust, and violence" (Vitus 1997, p.86). Daniel adds that "Islam was reckoned the greatest enemy of the Christian Church" (Daniel 1960, p. 186). Thus, this is the reason for Percy's play to be sued over spread of hate and disinformation.

The decorative Islamic images in Percy significantly suggest a consideration of its location on the English theatre. Percy's play is set in and around the mosque of 'Medina' in which the Prophet costumes 'all greene and greene his Turban' and that his Angels are 'rainbow powdered'. He appears with an Alcoran and silver crescent on his Turban (I.i). Percy's source to the appearance of Mahomet wearing in green colour is mentioned in Hakluyt (Hakluyt 1600, 
p.103). This scene depicts the Prophet and the angels look like dreadful and puckish. The appearance of Mahomet costumed in green is a Sufi practice in Islamic cultures. According to Hadith Tradition, the Prophet liked white (Alnassai 2008, no.5323). The turban is a headband generally worn by Muslims in the Elizabethan imagination for the big Turkish turban. The headdress is introduced in a comic presentation upon the role of the image of a Muslim personality. Furthermore, Mahomet's moustache appears to have been exactly related to the Ottoman Turk in Elizabethan age, and mostly on the playhouse. These mocking themes highlight and endorse the English writers were confused over their recognition to the crosscultural threats of Elizabethan fascination in the Ottoman civilization. In fact, Percy's "Mahomet" is Christian-like. For instance, he has a decorated mace that is carried by or put in front of particular public Christian officials as a symbol of their authority in the Church. Percy represents Mahomet look like a deity but the figure is not so since he threatens to destroy only Arabia and not the entire world. Contrasting with the Christian God, Percy's Mahomet similarly rejects to offer any compassion for Arabia and its people till pressured by force when Gabriel "held him by the Bearde, or clawd him by the face if for Poules" (I.i.40-41). This comic play exploits the contrast between Mahomet and Christ to plea for Christian understanding.

The Elizabethan audience inaccurately realizes that Prophet Muhammad acts as the saviour of the Muslims. Ensuing Haly's unanticipated arrival and successive submission, he asks Mahomet as his Saviour saying: 'I may be accounted one worthy but/To hold the Booke unto my Saviour' (V.xiii.70-71). Dimmock comments on that this image of "the word 'Saviour"' is only a "conception of Christ in the New Testament" (Dimmock 2006, p.33). In addition, the names of the Muslim characters such as Chiause, Dervis, Fryar Geber and Belpheghor, Lawyer are frequently modified between Christian and Turkish terms. Comparatively, a variety of Christian religious practices are cited, and some of these Muslim characters in the play swear in a mistakenly Christian, even Catholic style such as the Devis swears by 'Sancto Domingo' (III.i.37), Belpheghor swears by Saint Anne (IV.ix.61), Sergius swears by 'Mary Mieu' (V.xiii.110), and the divine spell the angels communicate to Epimenide encloses an allusion to Saint Beade (IV.iii.71). Percy attempts to abrogate Islam and Muslims by dehumanizing their Prophet and religion. Haly, Chiause, Dervis, Geber and Belpher are all corrupt Muslims. Vitkus remarks that "the stereotype of the devilish Moor or cruel Turk was sometimes employed to demonstrate the supposed iniquity of Islam and to portray Muslims as agents of Satan" (Vitkus 2000, p.15). Muslims were seen to be "different and strange, infidels and 'barbarians,' admirable or fearsome" (Matar 1999, p.2). For Percy, the Islamic ritual episodes are totally laughable in contrast to Christianity; the Dervis would not be instantly noticeable as a 'Fryar', nor the Chiause as a 'Lawyer'. This portrayal resembles thoroughly the insincerity of the Dervis who is substantiated to be a 'superlative knave' and joins in a prevailing comic suspicion concerning the general practitioner of well thought-out religion.

The European controversial writings labelled Muhammad as an overambitious man involved in the founding of new religion, to clash with Christianity (Kidwai 1997, p.2). Percy's thoughtful paralleling primarily establishes a perfect separation between Islam and Christianity, and encourages a restrictive identification between the two in which Christianity symbolizes the true religion, and Islam its ruined replacement. For instance, Mahomet is also portrayed as a demigod - part mortal and part divine. Sergius, the priest to Mahomet, criticizes Mahomet for his imbalance privilege when he heard that the two angels told the heavenly spell to Epimenide. Sergius certainly uses it for his own conclusion to rebuke Mahomet, as 'for gaine, not onely/Thou hast prolld into thy Prophets Privitye,/But also taught it Man' (V.xiii.102-4). The mutual supposition that 'Mahound' takes a seat as a mediator in an Islamic heaven, is a projecting idea in Percy's Mahomet and His Heaven, which opens with a visualization of Mahomet encircled by his angels wailing with 'fury kindled Indignation' for the closure of 
decency on Arabia (I.i.10). Percy's comedy depends on the equivalent frame of Christian myth adjoining Prophet Muhammad that enlightens the audience. Like this is in Robert Greene's Selimus (1594), the Turkish Sultan Selimus scorns Prophet Muhammad and Islam:

Let Mahound's laws be locked up in their case,

And meaner men and of a baser spirit

In virtuous action seek for glorious merit.

I count it sacrilege to be holy,

Or reverence this thread-bare name of good. (I. ii. 12-16)

These toxic lies depict hectic and corrupt accounts on Prophet Muhammad, his family and followers and they establish hate towards Islam. For instance, Percy represents Mahomet as a magician. This account provides a fertile ground for misunderstanding Islamic theology. The superstition is part of the incantations and amulet recited in the play and indicates the lack of knowledge in the West about the teachings of Islam and its Prophet.

Percy dramatically raises anti-Islamic prejudice up to the surface in mocking assaults on identifiable and visible traits of Islam and Muslims. It is entirely an instance of mudslinging to take delight in a prejudiced view of Islam. The audience is obsoletely jolted by the scene as it is disgusting. This bogus information comes in a variety of forms, including false or erroneous accounts to confront Islam in the play. Percy's harsh approach to Islam and Prophet Muhammad is against the truth to represent the Messenger Muhammad as a wicked dirty juggler. Furthermore, the image of the sexual life of Prophet Muhammad is a product of Western fantasy and is not rooted in reality (Armstrong 1991, p. 190). In the play the Muslim woman Epimenide deceives Angels, Mahomet and Muslim men; the "lustful Mahomet" attempts to entice her but she rejects his suit. Percy degrades the Prophet by playing upon extensive Christian notions of his lasciviousness (Burton 2009, p. 171). Percy is evidently creating a polemical argument by humiliating Mahomet, playing upon general and repeated Christian traditions of his sensuality, a conspicuous Medieval element of the Prophet's legends. Tariq Ramadan points out that 'Polygamy was the norm in Arabia then, and the Prophet's situation was the exception, since he remained monogamous for twenty-five years' (Ramadan 2007, p.75).

Percy's play assigns significant consideration to religion and drinking particularly as it refers to Islam. The play's various allusions and images of drinking prompt and reveal innovative understandings about Anglo-Islamic encounters (Ebrahim 2015, p.157). Dimmock states that the Islamic prohibition of alcohol was a reason of significant interest in Christian writings throughout the Medieval and Elizabethan periods (Dimmock 2006, p.21). The theme of Muslims drinking alcohol is used by William Percy to criticize the Holy Qur'ann as it is imperfect to its followers to observe. Percy links Bacchus, the God of wine, thoroughly with the luxury and superfluousness of the Islamic heaven and Arabian Peninsula (II.vi.5 and III.v.17) is mentioned in Nicolay's Nauigations when he falsely refers to Muslim priests 'calling vpon Bacchus' (Nicolay 1568, p.125). It is ridiculous to find this account as it is part of misinformation. Mandeville records that the Muslims do not drink wine for the reason that "Alkaron ... forbiddeth them to drink any wine... Mahomet curseth all that drink of that wine, and all that sell it" (Mandeville 1982, p. 95). The hatred of Prophet Muhammad and Muslim characters is the result of disinformation and propaganda. By mocking Islam, Percy interrogates the authenticity of Islam as a true religion. He accordingly expresses the invalidity of an organised religion that its Prophet, angels and followers are drunkards. For example, the hypocrisy of the Dervis or Sergius as the fictional monk in the Christian myths as assistant to the establishment of Islam is a prejudice directed against Prophet Muhammad, the Qur'ān and the other Muslim characters. Moreover, the short episode of Haly (i.e. Ali ibn abi Taleb), the 
cousin of Mahomet, renouncing his Shia sect of Islam to join Mahomet's faction, proves provocative as it is falsely attributed to the personality of Caliph Ali who was fully brought up and died in the Sunni Tradition of the Prophet.

The demonization of Prophet Muhammad and the Holy Qur'ān is an egregious illustration of fake and misleading information. The play has many remarks which offend Islam and the Qur'ān. For instance, the angels open the Qur'ān that Mahomet is holding at random, and whoever gets the leaf (or page) with the highest number wins (V.viii.57). The Qur'ān like the Bible is a holy book. Muslims show respect towards the Qur'ān as similar as or higher to the way Christians respect the Bible. The intense dramatic dislike towards Islamic legislations and culture spreads misinformation and furious criticism of Islam in England. It sparked a national debate about the potential threat posed by conversion to Islam as in Daborne's A Christian Turn'd Turke (1609). The way of spreading misinformation about Mahomet helps to disturb understanding the truth of Islam. In Daborne, it is a sneaky method in representing a fake idol head of Mahomet to place a fake emphasis on Muslims' religious affiliation and adherence.

Percy establishes an image of Islam that is based on a version of Christianity, and also he usually attacks Islam to criticize Elizabethan Christian principles. Dimmock notes that "the ninth earl's copy of the 1543 Alcoran is bound between covers on board that feature portrayals of classical gods and emperors" (Dimmock 2006, p.247). The Medieval and Elizabethan writers were obsessed with the ways in which they considered the Noble Qur'ān to be 'far from divinely inspired' but rather, 'manipulated by Muhammad to serve his own base desires' (Tolan 2002, p. 152). There are numerous examples of the ways in which this 'plan of general sexual license' was intended as 'an instrument for the destruction of Christendom' (Southern 1962, pp. 29-30, \& Watt 1991, p. 86). Percy's critique of Islam is directed at the 'Alcaron' which appears often in the episodes. For instance, the Christian myth of Muhammad's dove is rooted to Sergius who is called in the play as the Christian tutor to Mahomet. The historian Sebastian Munster reports that it was not Sergius but Mahomet who is more frequently assumed to have 'accustomed and taught a Doue to be fedde, and fetche meate at his eares, the which Doue his moste subtile and craftye maister called the holy Ghoste' (Munster 1574, p. sig. I. 3v). This particular sort of tale developed in Elizabethan interpretations of divine revelation to Prophet Muhammad. This mainly significant example of a seemingly false miracle is argued in Daniel (Daniel 1960, pp. 257-66). Andrew Boorde, for instance, inscribes,

The Turkes hath a law called the Alkaron Macomyt a false felow made it, he seduced the people vnder thys maner, he dyd bryng vp a doue and would put .ii. or thre pesen in his eare, and she would euery day come to his eare and eate the peason, and then the people would thynke the holy goost, or an Angeli did come \& teache him what the people should do.(Boorde, sig. N. lv.)

Percy is likely to have encountered Cluny's text in the abridged version that accompanies Theodore Bibliander's sixteenth century Latin translation of the Qur'ān, the Machvmetis Sarracenorvm Principis Vita Ac Doctrina Omnis, Quae \& Ismahelitarum, \& Alcoranvm dicitur... (Basle, 1543) (Dimmock 2006, p.182). Haly or Ali ibn abi Taleb, is described as 'the sole Author of that contrary Sect' (V.xiii.19). He arrives with a symbolically diverse band of followers who represent all the souls 'that dyde in the Schisme' (V.xiii.3). Haly renounces his own "Alcoran," the veracity of which he had conveniently been "but doubtful off" (V.xiii.47), and subscribes to Mahomet's book, thus healing Islamic religious division. Dante, in The Divine Comedy: Inferno, shows hostile illustrations locating Muhammad and Ali in Hell, with their bowels hanging out (Canto 28): "See how I split open the crack in myself! See how twisted and broken Mohammed is! Before me walks Ali, his face Cleft from chin to crown, grief-stricken (Zimmerman 2003, p.191). In Skelton's lost play The Nigromansir (1505), 'Muhammad is grouped with such figures as 
Herod, Judas and Pilate, all of whom Skelton consigns to Hell' (Aljubouri, 182). In 1565, the Bishop of Salisbury instituted a prayer for Wednesday and Friday services to cure the "wicked monster and damned soul Mahumet" (MacLean 2007, pp.1-2). Percy works on the supremacy of Mahomet's image in the world to a hypothetically disturbing dramatic perspective. The importance of this play lies in the ways Elizabethan England conceived religious difference. Percy's anxieties are based on England's sense of paranoia about the Islamic Ottoman Empire.

The mocking presentation of Mahomet's divinity is characterized in a falsified miracle since it has its origins in the Medieval arguments. Some Christian legends refer to Mahomet's miracles such as the myth of his 'floating tomb' in the air for eternity, the Christian 'pigeon' to Mahomet, the Christian Sergius as the learner and founder of Islam, the pagan superstitions, and the supernatural conception of Islam and the Prophet (Daniel 1960, p. 105 \& Brigden 2000, pp. 956). Percy's work promotes flawed understanding of Islam and the Prophet. For instance, the heaven spell that moves various characters to Mahomet's paradise is a curious blend of the divine and the sacrilegious. This indicates the multi-faceted understanding of the Prophet in Christian thought which is to falsify and demonise or even mock any evidence of the nature of true divinity support Prophet Muhammad. But this approach brings together Muhammad and Christ as divinities while Percy attempts to prove the major difference. This contradiction seems unavoidable in showing Prophet Muhammad on Elizabethan stage.

\section{MAHOMET'S HEAVEN}

Mahomet's Heaven is an inverted and demonized fictional world, but to some extent it is like a real universe. The play is not mocking an Islamic model of heaven but this model as a site for humour. The plot of William Percy's Mahomet and His Heaven (1601) is more in Arabia than in heaven. It contains component of the Christian polemic of Islam in the Elizabethan Era which are inherited from the Medieval Age. Early modern writings are typically established on negative stereotypes about Prophet Muhammad and the Revelation of Holy Qur'ān which are formerly interpreted into assaults on Muslims. For example, Percy's show refers to an alleged myth of the Qur'ān from numerous traditions that Muhammad is teaching a dove to peck wheat from his ear to claim that it personifies the Holy Spirit. Likewise, Christian accounts assume in one way or another that all Islamic teachings are made to serve Muhammad's lust. Although Percy's play is an Elizabethan work, it still echoes the same fascination with Islam and polemical matters that had been repeatedly noted in Medieval centuries. In fact, the most significant Medieval travelogue, Travels of Sir John Mandeville (c.1356), comments on some themes of anti-Islamic polemic: the prohibition of wine, the luxurious Islamic paradise and Mahomet's epilepsy (Loomba and Burton 2007, p.70). The comic play chokes full of greed, hypocrisy, and the occult. The contention is that Islam functions as an inversion of Christianity - as Anti-Christian. In The Manners, lawes and customes of all Nations, Edward Aston argues that the "incredible allurement" of Islam has been Mahomet's "giving to his people free liberty and power to pursue their lustes and all other pleasures, for by these meanes, this pestilent religion hath crept into innumerable Nations" (Aston, 1611, p.137). For instance, Shakespeare claims that the sexual corruption of Islam has "outparamour'd the Turk" (King Lear, 3.4.91 -92). Percy misrepresents the inaccurate information of Islamic polygamy to disgrace Islam. Generally, Islam identifies merely the union of man and woman as a required arrangement of matrimony. On the other hand, under extraordinary conditions it permits the man to marry four women. Meanwhile, Islamic polygamy was to assist a great communal purpose of society, the following verse of the Qur'ān plainly points to a significant purpose of polygamy. The verse states:

If ye fear that ye shall not be able to deal justly with the orphans, Marry women of your choice, Two or three or four; but if ye fear that ye shall not be able to deal justly (with them), then only one, or (a captive) that your right hands 
possess, that will be more suitable, to prevent you from doing injustice (The Holy Qur'ān, Interpreted by Yusuf Ali, Verse, 4:3).

The Christian interpretation of the Islamic matters in the Holy Qur'ān was hardly accessible in early modern England. Percy's play gives unique impression in incorporating very little knowledge of Latin interpretations of the Qur'ān, on the stage. To this point as its theme is actually apprehensive, Mahomet and His Heaven is greatly creative over the story of Haroth and Maroth. Percy has simply taken the story from the historical records though it is not approved by Muslim scholars (Dimmock 2006, pp. 182-3). In fact, the Qur'ānic origin of Percy's plot of Haroth and Maroth includes a verse on the world's reception of magical science which was earlier explained by few scholars into a Muslim legend of two angels sent by the Almighty Allah to endure enticement and judge human beings. In contrast to this view, many other great scholars of Islam do not approve this interpretation as it is taken from the Babylonian Jewish Talmud (Ibn Katheer 1999, p.360). Then again, Percy likely admires the tale in the essence of "medieval anti-Muslim refutation that depends upon exposing absurdity and comedy at the heart of Islamic theology" (Dimmock 2006, p.22). Percy's Mahomet as being concerned by Arabia's evils, he vowed to annihilate the Arabs by drought but then he stopped by Gabriel, and sent two angels down to re-examine the matters.

Percy establishes an Islamic universe that is the darkest of Christianity in which Mahomet lives in heaven and is perceived as a deity by the Arabs. His cosmos is relatively attached with the Christian universe but compared to Christian values and theology, it is corrupt and blasphemous. The figure of Mahomet is shown to be agitated over corrupt stories of widespread sinfulness in Arabia and intimidates to overwhelm the Arab people. Gabriel drives Mahomet into probing information of the sins rather than just accepting the information and meting out tough punishment (I.i.40-41). Mahomet sends Haroth and Maroth (masked as travelling minstrels) to spy on the Arabian nation. They discover sin and vice in every city they visit. They want to search the desert for righteous people. Therefore, they join Epimenide's followers. Percy's emphasis is primarily employed upon the naivety of the angels and the subsequent reliability of Divinity of Mahomet, who dispatches Haroth and Maroth across to earth, and they are guided not to judge manhood but to protect the Islamic universe from godly demolition. Percy's delineation of Islamic theology is full of confusion. For instance, a sarcastic subplot includes the conveyance to heaven of a lying lawyer and adulterous Islamic friar in challenge between the spirits of wind and fire, Whisk and Pyr, to conclude who can take the utmost scoundrel to heaven. When the two spirits yield to the test of the "Tankard of Trial," they become superlative scoundrels, so the quarrel is reserved to Mahomet to be ruled on along with the betrayer angels on the judgement day alongside the adulterous marriage of two couples. Another episode is the appearance and repentance of Haly, the son-in-law for his inventions separated the Sunni from the Shia. On earth the angels fall in love with an earthly woman Epimenide who deceits them and got the spell on how to fly like them to Mahomet's heaven. When Epimenide reaches heaven, she takes advantage to insult Mahomet and makes a great disruption till she is put into a deep sleep till the doomsday. When Mahomet meets Epimenide, who is the long virginal, lust-provoking, evil-tempered, he is shown to be lured by her. She has previously enticed and bewitched the two pastors, a mage, and Maroth and Haroth who unveil their holiness, the prayer to proceed to heaven and pledge her for sex. In paradise, she is imprisoned for her sins and for her handcuffing Mahomet on the ear. However, the lubricious Mahomet still enthused by her magnificence, he recalls her for love but she invited him to "kiss [her] cul" (V.iv.6). She contemptuously denies his advances. Later, Mahomet expels Epimenide and the wicked angels Maroth and Haroth to the moon (V.xiii.83). Epimenide's punishment is life imprisonment in the moon with a shamed angel on every side of her, one to scream in her ear, the other to murmur quietly. When the quiet angel prevails, the weather 
goes fair, and when the loud angel prevails, the weather goes stormy. Mahomet accomplishes with punishments and blessings. Although absurd in some former instants, the character is given an antichrist-like enormity in the verdict section.

Percy's Qur'ānic portrayal of paradise contains several features such as very beautiful women, rivers of wine, milk and honey, treasurable drinking and eating pots, thrones of precious ornaments; places that are incorruptible, unlimited and luxurious. Nonetheless, Belpheghor's reference to 'our olympick Toung' looks like a uniquely classical place. Percy's account to Mahomet's paradise is as 'olympus' and Deity as 'the Immortal Jove' (V.iii.2-3). This account is typical of Elizabethan theatrical images of the Islamic Divinity, which is a careless allusion of ignorance and possibly blasphemy. Percy's claim to Mahomet's heaven has a mass of classical Gods such as 'Apollo' and 'Jove' sit together with 'Mahomet' (V.iii.61-2) (Matar and Stoeckel, 2004, pp. 220-52). Norman Daniel has documented that 'it was the Islamic Paradise which, more than any other theme, summed up the Christian notion of Islam' (Daniel 1960, p.172). This Islamic Paradise is vigorously in depth as a place for perfect human happiness and luxuriance in contrasts with 'a purely spiritual apprehension of God in the ecstatic vision of the Christian tradition' (Daniel 1960, p.172). William Tyndale states that the Turks pray to God not 'as his godly nature is to be worshipped, but after their own imagination', not 'in the spirit, with faith, hope, and love', but 'with bodily service' (Tyndale 1940, p.181). This Paradise, wideranging with cheerfully existing virgins, lavender and treasures, symbolized this supposition and hence overwhelmingly showed its morality, 'plainly contrary to the natural and divine law' (Daniel 1960, p. 176). However, Percy has placed Mahomet at the centre of depictions of the occult in associating him with the 'dark arts' of magic (III.iv.59). Such practice of a ritual spell of the magic arts one can reach the Islamic heaven in the earthly realm of Arabia. This spell challengingly blends the sacred and the profane. It is the means by which man passes from the earthly to the heavenly kingdom, and it is a bizarre combination of components:

Come Alah Nosters five,

Come Maumets, ten-by-five,

Appeare thou Credo once,

With three Amens atonce,

Faire Angeli, white and bright

As Candle, or Glowe worme light

With wings all painted ore,

As is an Alehouse doore,

To heaven so and so

Round, as St Beade, I goe. (IV.ii.62-71)

Dimmock comments that the spell is more Christian than Islamic. The 'Alah Noster' is Paternoster, Latin Lord's prayer. The allusions to Christian theology, to the Latin Credo, to Amens and to St Beade are referred in the other lines possibly to recommend the echoes associated with the formal procedure of Catholic confession (Dimmock 2006, p. 45). Indeed, Percy unambiguously foresees Islam as a distortion of Catholicism, and the abundant references to Saints further endorse this picture in place of the painted Archangel. The Elizabethan wine of 'Alehouse doore' is associated with the significant variety of liquor procurable in Percy's Islamic heaven. Therefore, Dimmock concludes that Percy's description to "Mahomet's heaven is a kind of pure fiction, where no Christian values can be threatened" (Dimmock 2006, p. 21). To label Mahomet directly as a superior juggler might confuse the audience to think over the holiness of the Prophet as an antichrist or a mirror-image of the Saviour to Muslims. Therefore, Percy links Mahomet with the figure of scientist Geber in order to make a humorous remark on his achievement in alchemy and astrology. Percy abuses Mahomet and Geber in associating Islam and Muslims with sorcery. 
Epimenide is the Grand Empress of the Arabian Deserts. She is a sickly but pleasantly beautiful woman. She is capable of disturbing the world of Mahomet. By temptation, she plays on all characters including Mahomet. She successfully seduces Caleb and Tubal to steal Geber's ring and purse for sleeping with them. In exchange of sex, she makes the lustful angels Haroth and Maroth as demeaned servants for her and they teach her the holy spell that can take her to heaven but she scorns and rejects their suit. She feels proud of herself as she has occult powers given to her by the mysterious angels. In heaven, she heroically challenges Mahomet's authority and wishes to have wealth and power to gain access to the entire heaven besides the Deserted Arabia. Even though Mahomet realizes her ambition, he falls in love with her. She effectively cheats and betrays everyone as well as everyone falls in lust and betrayal in heaven or on earth.

Percy introduces Mecha as a centre of superstition for the followers of the Prophet. In Epimenide's absence episode, Nabatha, Epimenide's maid, and her friend Shebe miss Epimenide so they travel to Mecha to ask the tutor Sergius her location. He informs them that she has gone up to Heaven, and said that they will both be wed the same night. Robed in their marriage attire, the two women run into Caleb and Tubal near Mecha and inform them of Epimenide's destiny. In Mecha, Sergius transfers the four to Heaven to get Epimenide. Later, Mahomet deals well with Nabatha and awards her Tubal as a husband for her loyalty and he betroths Caleb to Shebe. In heaven on the Day of Judgement, when the characters are assembled, Mahomet asks the killers to lock Epimenide up. He meets Adriel, Gabriel and Metraon to permit judgment on Epimenide, Maroth and Haroth. The judgment is disturbed by Mahomet's opponent Haly, who abandons his schismatic traditions and declares himself truthful to Mahomet and his 'Alcoran'. The ceremony is again broken up by the appearance of Sergius and his suitors and Belpheghor and his quarrelling parties. After the episode of deporting Epimenide into the moon and asking the sinful Maroth and Haroth to hold the moon as it turns (V.xiii.83), Mahomet instructs Chiause to work in transferring water for infinity and Friar Dervis to walk lightly by his side calling sacredness. He also commands the executioners to lash Belpheghor and Sergius for getting human beings into Heaven. Finally, Mahomet concludes the decrees gathering by glorifying God. The show finishes with a celebration of sacred association in a song incited by Mahomet who saved Arabia. Percy ridicules Mahomet but he makes a unique final scene of sacred understanding.

The Muslim or angelical characters are mutually represented as agents of Islam in a Christian manner. Matthew Dimmock states that the difference 'between the conventional doctrine of the 'Christian' and this deeply alien set of Islamic beliefs is intentionally profound' (Dimmock 2005, pp. 180-81). Tahar Bayouli notes that the exoticism and the fascination in discovering the Eastern world remain a significant feature to the attractiveness of the Oriental drama in Elizabethan drama (Bayouli 2008, p.116). The reproduction of Islam as a corrupt version of Christianity is evident from the beginning of the play. Mahomet's 'fury kindled Indignation' (Li.10) with the evils of manhood motivates him that demolition is the merely medication. He screams that the 'soule-perplexing memory' of man's iniquity,

Hath swoln my hearte with that Indignitye,

That by the holy Alcoran I sweare,

Before twise and twenty dayes have run their courses,

From East to West, from West to East, I will

Destroye, by this now mortiferous drough,

From Arabia each Mothers offspring. (I.i.24-30)

According to the Old Testament "God looked upon the earth, and, behold, it was corrupt; for all flesh had corrupted his way upon the earth. And God said unto Noah, The end of all flesh is come 
before me; for the earth is filled with violence through them; and behold, I will destroy them with the earth" (Genesis 6:12-13) (Carroll and Prickett 1997, Genesis 6:12-13). Therefore, Percy hinges on showing absurdity and humour at the heart of Islamic spirituality in introducing comic encounters between a classically English lawyer who becomes a comic Chiause, and an English churchman, Dervis. The negative exaggerated attributes of these Muslims are emphasized in falseness, sexuality, greediness to distort the images of Islam, Muhammad and Muslims. For Percy, Prophet Muhammad is a deity in a collection of fabulous tales to disprove Islam and to establish that the Qur'ān is not the God's message of an authentic revelation. The play sorts a great arrangement of explanation and highlighting, while it is totally restrained to the common Western refutations rather than the significant transcript of the 'Alcoran'. For instance, while the plot of Haroth and Maroth is in an Islamic account in a short context of the Noble Qur'ān, the play springs from a Christian controversial tradition that interprets Islamic accounts for polemical determinations. Some information of the Holy Qur'ān may be established in three places of Act 5 Scene 6 that look like to parallel with Abdullah Yusuf Ali's English translation for Surah II Al-Baqarah (The Heifer, verse 102, p. 14). These images of an Islamic paradise are explained by Belpheghor to his friends as they fail to anticipate the divine meaning of paradise. The Elizabethan traveller George Sandys describes how 'all such men/As in this world had Wives constant and true,/Shall in the other, not enioy so few/But Concubines aboundance, with eyes cleare, And great as egges' (Sandys 1610,p. 253). For long centuries, the interpretations of the Qur'ān have been banned by the entire Western church to avoid understanding Islam and promoting Islamic supremacy. Nabil Matar notes that during this period "Islam left its mark on Britain in a way that was unparalleled by any other non-Christian civilization which the British encountered. At this stage in history, Islam could neither be ignored nor 'dominated' (Matar 1998, p.38).

This distortion suggests a connection between the play and the Medieval tradition of refuting Islam even with false accounts. The themes exploit Islam in the negative light of the occult, alchemy, astrology and religion. It is, therefore, not unusual that Percy clearly participates in this tradition. He deliberately incorporates false information into his satirical attack on Prophet Muhammad. The misrepresentation of Islam is a result of the deceptive nature of the religion that Percy tries to attach monstrosity to. Percy also makes a comic and satirical presentation on the life of Muhammad (PBUH). In the episodes, Percy intends to show Muhammad as a wicked man, and a supernatural character as in animated series fairies. These offenses are based on a Christian enthusiasm though they are represented in scornful scenes. The method that can make people comic can serve a hostile and aggressive purpose in order to make them contemptible or to deprive them from their dignity and authority. Such mimicry, disguise, unmasking, parody, etc. are devices that put the comic subject in a ridiculous situation inspiring laughter (Akalin 2001, p.296). This Elizabethan inclusion of Muhammad's portrayal is part of religious hate and hostility towards Islam and Muslims.

\section{MUHAMMAD IN ISLAM}

Percy's negative representation of Prophet Muhammad runs counter to the real life of the Prophet. Islam and Muslims are misunderstood as the natural and irreconcilable enemies of the Christianity and the Europeans. The portrayal is set by the Medieval scholastics and it is the root of the indeterminate response to challenge of the religion of Islam. This response is a combination of mistrust, misapprehension, anxiety and interest regarding Islam, and a result of the clash between a set of understandings well-versed by Medieval controversial and presentday political and commercial pressures. It is this clash formula that stimulates Percy's peculiar melodramatic reaction. Early Christian writers critiqued Islam for promising sensual pleasure to the righteous as a prize in the next life; they similarly judged the sexual freedom permitted in this life under Islamic law. Daniel states that "Islamic regulations governing concubinage, 
marriage, and divorce were misunderstood and reviled by Western Europeans" (Daniel 1960, pp.135-40). However, Percy clearly wants to accomplish disadvantages by constructing suspicions about the genuineness of the Qur'ān straight as Muhammad's own work, claiming by himself as the word of God. Harry Dorman states:

It (Qur'ān) is a literal revelation of God, dictated to Muhammad by Gabriel, perfect in every letter. It is an ever-present miracle witnessing to itself and to Muhammad, the Prophet of God. Its miraculous quality resides partly in its style, so perfect and lofty that neither men nor jinn could produce a single chapter to compare with its briefest chapter, and partly in its content of teachings, prophecies about the future, and amazingly accurate information such as the illiterate Muhammad could have gathered of his own accord (Dorman 1948, p. 3).

The anxiety of the transcultural impact of the Islamic civilizational integration in the West might bring cultural diversity to England. To prevent Islam is to play down suspicion of assimilation with the culture and religion of Muslims. The underrepresented depictions expose Percy's struggle against Islam's challenge in England. The Elizabethan hostility towards Islam and the Ottoman Empire was of the scepticism of integration. The fear trend intensifies in negative underrepresentation the religious symbols of the Ottoman Islamic World such as the Prophet and the Qur'àn. The appearance of Mahomet as the archetypal "false prophet" is part of intra-Christian religious polemics accusing Muhammad as the writer of the Qur'ān; and this portrayal indirectly advances one of the key arguments of Medieval Christian thinkers against Islam: specifically, that the Noble Qur'ann is not a heavenly revealed text but the human work of a pseudo-prophet. Such uncertainties, as established in this play, are indeed typical of LatinChristian responses with the Qur'ān and Islam in general. Matthew Dimmock comments on this closed view that the image of false Muhammad exists in the British mindset:

This fabricated figure and his spurious biography were endlessly recycled, but also challenged and vindicated, and the tales the English told about him offer new perspectives on their sense of the world - its geographies and religions, near and far - and their place within it. (Dimmock 2013, p.1)

Nabil Matar states that during this Renaissance period "Islam left its mark on Britain in a way that was unparalleled by any other non-Christian civilization which the British encountered. At this stage in Britain history, Islam could neither be ignored nor 'dominated' (Matar 1998, p.184).

The critical investigation of Islam and Muslim manners needs not to be overlapped by impoliteness and ignorance. Elizabethan dramatists usually portray Muslim Turks and Moors in a negative light. Benn and Jawad state that enmity towards Islam and Muslims are narrowly linked to the representations of "Islam as barbaric, irrational, primitive and sexist" (Benn \& Jawad 2004, p. 165). Prophet Muhammad's character and personality is entirely the opposite than Mahomet that is represented in the play. The appearance of a distinct Muslim identity in Europe is the reason of negative feelings and attitudes towards Prophet Muhammad and Muslims. Percy also refers to the Prophet in a negative light, presenting him as a heavenly character with strange sexual desires, a godlike person who prepares rules to suit his desires. This is totally disgraceful and scandalous in view of the truth that Islam is a religion which defends ones dignity. In Islam, a Muslim cannot have sexual contact with the opposite sex without marriage. Polygamy occurred long before the appearance of the Prophet, and Percy seems unaware of its sustained social role. Dr. Westermack remarks on polygamy and states:

There has been much loose talk and irresponsible criticism of polygamy in Islam. The critics dub polygamy as evil. They say that this "immoral" and 
"obnoxious" practice causes much distress in family life. It is also alleged that polygamy is prompted by the lower self of man; it is resorted to by men who are devoid of refined sentiments and who have no regard for the demands of even elementary justice. That is how they pave the way for attacking Islam and its Prophet (Westermack 1933, p.78).

Percy has read his own false assumptions onto the life of the Prophet. Such an approach is entirely corrupt and untrue. The absolute negativity of Percy's description of the Prophet as a licentious man, is absolutely untrue and without foundation. The mainstream of modern Western sources and books deny the Medieval Christian and Western misinformation about Islam and Messenger Muhammad. They describe Prophet Muhammad as a man with dignity and enormous knowledge claiming that his knowledge came from God the Creator (Watt 1991, p.37). Moreover, he is appreciated and admired by several Muslims as well as non-Muslims. For instance, Stanley Lane Poole, an enemy of Prophet Muhammad and Islam, respected the Prophet when he called him "the Great Man Muhammad" (PBUH). He says:

He was the most faithful protector of those he protected, the sweetest and most agreeable in conversation. Those who saw him were suddenly filled with reverence; those who came near him loved him; they who described him would say, 'I have never seen his like either before or after.' He was of great shyness, but when he spoke it was with emphasis and deliberation, and no one could forget what he said (Poole 1882, p. 27-8).

The visual depiction of Prophet Muhammad is mentioned in the Tradition [i.e. Hadith] of the Prophet. In the Islamic art, the painting of Prophet Muhammad is not preferable. Charles Eaton examines the avoidance, and he finds out that 'the key concern is that the use of images can encourage idolatry' (Eaton 1985, p. 207). The Muslim artists do not make images of Prophet Muhammad, and Muslims understand that "the images are not objects of worship. Nor are the objects so decorated used as part of religious worship" (Gruber 2010, p.27). The pictorial depictions show Prophet Muhammad with his face veiled, or metaphorically show him as a flame, are all invented (Gruber 2013, pp. 30-31). The Messenger Muhammad (PBUH) is a man preferred by Allah the God to be his Messenger. And when William Percy sorts the Prophet look like a fool and compromise with the Greek deities, he has disrespected the religion of Islam and Muslims. Prophet Muhammad is a man with immense divine knowledge. He does not speak out of his own wish but of divine revelations. He speaks what is revealed to him by Allah, the Almighty who says: 'Your Companion [Muhammad] is neither astray nor being misled. (3) Nor does he say (aught) of (his own) Desire. (4) It is no less than inspiration sent down to him: (5) He was taught by one Mighty in Power" (The Holy Qur'ān 53: 2-5). Percy's play ridicules and humiliates Prophet Muhammad ignoring the fact that Muhammad was called the 'The Trustworthy' for his honesty before the Prophethood. Furthermore, the apocalyptic desert of Arabia is chosen to host the House of God, though it seems quite absurd for the Christians that God had not chosen a green land as a sacred site. Thus, Percy refers to the mission of the Prophet to purge the Arabs of their sins by a comprehensive drought (I.iv.19-20).

The Elizabethan attraction towards Arabian culture is noticed in the Oriental plays about the Arabian, Moorish and Turkish themes and characters. Vitkus states that 'Islamic culture is powerful, wealthy, and erotically alluring. For the Elizabethan playwrights, Islam is a religion of temptation (Vitkus 2003, p. 108). Schmuck notes that "during the Middle Ages, and up to the late Renaissance, England knew little and cared less about the Muslims and their culture" (Schmuck 2010, p.544). The churchmen describes the Prophet as the "wicked monster and damned soule Mahumet" (Dimmock 2005, p.148). Therefore, Percy's misleading and misdirected prejudices towards Islam and Muslims are to exploit the panic for the sake of the 
union of the English with the Christendom against the Ottomans. The message of Heaven brought to Prophet Muhammad seems unlikeable to the Christians as the new heaven message invalidates the Christian teachings which earlier invalidated the Jewish teachings. The Early Modern polemic depiction of Prophet Muhammad is a repeated propaganda of the early period of Islam when they family and the tribe of the Prophet rejected his teachings. The people of other faiths like Jews of Madina and Christians of Najran examined the Prophet and discarded his message. The Prophet continued his call to God who supported him and the entire unbelievers of Arabia turned Muslims. Till now, a small minority of Christian Arabs of Najran exists in harmony with other Arab tribes. On the other hand, the contrast between Muhammad and Christ is a sort of competition for the Christians which does not exist among Muslims. In Islam, Prophet Muhammad is a human being sent by God, the Creator of mankind. The message of Allah is stated in the Noble Qur'ān, "It is He Who has sent amongst the Unlettered a messenger from among themselves, to rehearse to them His Signs, to sanctify them, and to instruct them in Scripture and Wisdom,- although they had been, before, in manifest error" (The Holy Qur'ān: 62:2). Actually, MacLean remarks that Muslims consider Christ, 'whom the Mohammedan law in which you [Mehmed] were born calls a holy man, a great prophet, son of a virgin, and famous for his miracles (MacLean 2007, p.1). Martin Luther remarks that "The Qur'ān praises Jesus and Mary many times as being without sin. But it says nothing more than that he was only a prophet (Muhammad) like Ishmael and Jona. It denies that He is the son of God and that he is truly God" (Wolf 1941, pp.169-70).

The Prophet was on a heavenly mission from Allah the God to call mankind to Islam. Muhammad (PBUH) started calling his Arab people - pagans, Christians and Jews. He turned the Arabs into being more civilized. One of the pagan customs of some native Arabs was to bury their small daughters alive, thinking that women could be a source of disgrace to the tribe. The message of Allah the God, to Prophet Muhammad was to prohibit this tradition. Unfortunately, a person who has never learned or made out the history of Islam would be averted in reading Percy's provocative play. Percy has shown argumentative remarks to the Prophethood of Muhammad in many ways. In one episode, the Prophet is depicted wicked in hosting consent of a knavery. This is simply not true. Black magic or any sort of superstition is considered as blasphemy. It is a filthy bigotry lurking behind Percy's misgivings about Islam's reliable message to mankind. The Prophet's personality is on the perfect of morality. Allah the Almighty says: "And thou (standest) on an exalted standard of character" (The Holy Qur'ān 68:4). Prophet Muhammad worshiped neither an idol nor drank any wine.

The Elizabethan anti-Muslim prejudiced playwrights identify Islam as a colossal bloc, stagnant and uncaring to change. Matar notes that during the Elizabethan and early Stuart times the 'Britons encountered a powerful religious and military civilization which viewed them as an inferior people with a false religion' (Matar 1998, p. 3). Among the Elizabethan literary trends, the Islamic material in England is identified by Percy in a negative depiction of Prophet Muhammad and Muslims. To distort the character of the Prophet is the short way to falsify his divine message as a Messenger of Allah the God and the Creator. In Arabic, "Allah" is only the Arabic word for "God". Prophet Muhammad is sent to all mankind with a monotheistic Abrahamic message. The Prophet has called to believe in the God of Adam, Noah, Abraham, Ismail, Jocab, Moses and Jesus. His call is to believe in only one true God the Creator and his divinity or part of it is never given to anyone else; to pray five times daily; to observe fasting in the month of Ramadan every year; to give exact amount of alms on specific items every year; and to go for a pilgrimage to Makkah once a lifetime. Any earlier prophet had carried the same message including Messenger Moses and Jesus. The testimony of faith is the first to start: Allah has the right to be worshipped and He has neither partner nor son. This testimony of faith has taken thirteen years for the Prophet to convey it to the Arabs who used to come to Makkah for 
the pilgrimage during the entire year. This Islamic monotheism is the unique and absolute "oneness" of God, which in Arabic is known as Tawheed. Allah's attributes are all of perfection and completeness. None of human deficiencies can be ascribed to Allah. He has no deficiency or weakness at all: "There is nothing whatever like unto Him [Allah] (The Holy Qur'ān 42: 11). Therefore, none deserves to be worship but Allah, so the Muslims only worship Him. This is the core of Islam which means to submit your soul to Allah to be the called Muslim, the one who is submitted to Allah the Almighty.

\section{CONCLUSION}

The Elizabethan literary portrayal of Islam notably lacks true information. Percy's play is an odd play in depicting Prophet Muhammad. The play definitely approves the lack of knowledge about Islam or Prophet Muhammad. Early modern English notions of Islamic religious information can only be perceived in terms of the Christian distorted polemics and outright dubieties about Prophet Muhammad during the sixteenth and seventeenth centuries (Al-Olaqi 2016, p. 138). Therefore, Percy's misrepresentation of the life of Prophet Muhammad as scandalous is an identification of Islam as a heretical and false religion. The polemic distortion of Islam and its Prophet was a must for Christians to defend their religion. Thus, Percy's false information is intended to mislead the public especially in a theatre as a social institution. The play is very derogatory and strengthens prejudice against Prophet Muhammad. It is exaggeratedly abusive and offensive to Prophet Muhammad and Islam. The dramatist does not preserve the truth in his play which describes a fictitious character as the faithful Messenger Muhammad (PBUH) as replete with illusions that absolutely attempts to mock and abuse Islam and Muslims.

The West has been confused over the Prophethood of Muhammad. The horrible effect of this confusion creates more misunderstanding, ignorance and hostility. For instance, Percy's play is not much dramatically achieved by hurling insults at Mahomet and Muslim characters. The show has lost its literary grace because of its spreading fake hate hoax against Islam instead of facts. The copious polemical portrayal of Mahomet has been on the stage with the purpose of demonizing him as the antichrist. The dehumanization of the Messenger of Allah and Muslim characters has its origin in Christendom. The most outrageous claims of Christian schools of thought against Islam did not stop people from understanding Islam, Prophet Muhammad and Muslims. Islam is not the negation of human civilization. Islam is the real founder of the Western civilization starting from Andalusia. Vitkus states that "the demonization of the Islamic East is a long and deeply rooted tradition in the West-spanning the centuries, from the early medieval period to the end of the twentieth century. It harks back to ancient representations of Eastern empires and invading hordes that predate Islam, including the Assyrians and the Persians of the ancient world" (Vitkus 1999, p.209). Moreover, the West embraces the image of the terrible Turk as the infidel Other whose intent is to destroy the Christian world and who does not bother to distinguish between the Christian sects (Goffman 2002, p.109). To defuse the prejudice against Muslims, truth and better understanding to Islam and Muslims should take place instead of hate and bigotry.

The Western fear of anything Islamic is currently identified as Islamophobia which is a type of aversion to Islam. Thus, Percy's play is materialized in a way owing to the portrayal of Prophet Muhammad and Muslim people as the nationwide Other. Such fear mongers in Percy's Mahomet and His Heaven which shows Prophet Muhammad and Muslims as boogeymen to spur boisterous reactions from the English audience against the truth of Islam. History repeats itself in the current European repetition in displaying the images of Prophet Muhammad in the present media of the day which are not acceptable in the Islamic World. This stock of lies and misunderstandings are purposefully industrializing fear of Islam and contact with Muslims to 
understand Prophet Muhammad. Those misleading stories about Prophet Muhammad require the elite to track down and correct fake information and to end up the hate. The play degenerates into religious mudslinging in showing the faults of Muslims. Although Percy's antiMahomet hostility is perceived as natural and normal, the threat of misinformation has been overblown by the English literature to stir up Christian fanaticism. Therefore, Christians have sustained a vulnerable policy of sophisticated defamation of Islam and Prophet Muhammad all the way since the Middle Ages. The consequences of Elizabethan tolerance towards the spread of fake information about Islam and Prophet Muhammad establish solid misunderstanding in the West.

\section{NOTES}

Note: 1. The term 'Mahomet' is a corrupt spelling of Muhammad as it is a common English usage in sixteenth and seventeenth century as envisaged in Christian anti-Muslim polemic. In this study, the term 'Mahomet' refers to Percy's character while the spelling of 'Muhammad' refers to the Prophet of Islam.

Note: 2 . This article depends on a manuscript play that has, for the first time, been published in a modern, critical edition (2006) by Matthew Dimmock.

Note: 3. See Al-Olaqi, Fahd. (2010). "Image of the Messenger Muhammad (PBUH) in English Literature", Insights Journal, Vol 2, issue 4, July 2010. Islamic University of Pakistan.

\section{References}

Alnassai, Ahmed (2008). Sunan Alnassai. Ed. Muhammad Albanian. Damascus, Almaarf Press.

Armstrong, Karen (1991). Muhammad: A Biography of the Prophet. London, Phoenix Press.

Akalin, Esin. (2001). Discovering Self and Other, representations of Ottoman Turks in English Drama. Doctoral Dissertation, University of Toronto.

Ali, Abdullah Yusuf, (1997). (trans.) The Holy Qur'ān. AL-Madina, Mujama King Fahd.

Al-Olaqi, Fahd. (2010). "Image of the Messenger Muhammad (PBUH) in English Literature", Insights Journal, Vol 2, issue 4, July 2010. Islamic University of Pakistan.

Al-Olaqi, Fahd. (2013). "The Oriental Other Soliman the Magnificent in Kyd's Soliman and Perseda" TRAMES, 2013, 17(66/61), 2, pp.177-201. DOI: 10.3176/tr.2013.1.02.

Al-Olaqi, F. M. T. (2016). "Western Polemic Writings about Muhammad's Prophethood." Advances in Social Sciences Research Journal, vol.3, no.5, pp.138-156. DoI:10.14738/assrj.35.2001.

Aston, Edward. (1611). The Manners, Lawes and Customes of all Nations. London, G. Eld. http://name.umdl.umich.edu/A16282.0001.001

Bak, Greg. (1996). "Different Differences: Locating Moorishness in Early Modern English Culture." Dalhousie Review Vol.76 (1996): 197-216.

Bayouli, Tahar. (2008). "Elizabethan Orientalism and its Contexts: The Representation of the Orient in Early Modern English Drama" IJEMS. vol I, 1, pp. 109- 128.

Benn, T. \& Jawad, H. (2004). Muslim Women in the United Kingdom and Beyond: Experiences and Images. London, Brill Publishers.

Bennett, Clinton. (1992). Victorian Images of Islam. London, Grey Seal Books.

Biddulph, William. (1609). The Travels of Certaine Englishmen. London, Thomas Hameland. http://quod.lib.umich.edu/cgi/t/text/text-idx?c=eebo;idno=A68944.0001.001

Brigden, Susan. (2000). New Worlds, Lost Worlds: The Rule of the Tudors 1485-1603. London, Penguin.

Burton, Johnathan. (2009). [Review of the book] William Percy's Mahomet and His Heaven, (ed) Matthew Dimmock, Early Theatre, Vol 12, No 1 (2009): 171-3. 
Carroll, Robert and Prickett, Stephen. (eds), (1997). The Bible: Authorized King James Version with Apocrypha. Oxford, Oxford University Press.

Chew, S. C. (1937). The Crescent and the Rose: Islam and England during the Renaissance. New York, Oxford University Press.

D’Amico, Jack. (1991). The Moor in English Renaissance Drama. Tampa, Florida.

Daniel, Norman. (1960). Islam and the West: The Making of an Image. Edinburgh, Edinburgh University Press.

Dimmock, Matthew. (2013). Mythologies of the Prophet Muhammad in Early Modern English Culture. Cambridge, Cambridge University Press.

Dimmock, Matthew. (2005). New Turkes: Dramatizing Islam and the Ottomans in Early Modern England. Aldershot, Ashgate Publishing Ltd.

Dimmock, Matthew. (2006). William Percy's Mahomet and His Heaven: A Critical Edition. Burlington, VT: Ashgate Publishing Ltd.

Dorman, Harry Gaylord. (1948). Towards Understanding Islam - Contemporary Apologetics of Islam and Missionary Policy. New York, Columbia University Press.

Eaton, Charles Le Gai (1985). Islam and the Destiny of Man. State University of New York Press.

Ebrahim, Fatima F. (2015). "Turning to Food: Religious Contact and Conversion in Early Modern Drama" Electronic Thesis and Dissertation Repository. Paper 2796.

Fletcher, Giles. (1597). The Policy of the Turkish Empire. London, Iohn Windet for William Stansby. http://quod.lib.umich.edu/e/eebo/A14028.0001.001?rgn=full+text;view=toc;q1=Policy+of+the+Turkish+Empire

Goffman, Daniel. (2002). The Ottoman Empire and Early Modern Europe. Cambridge, Cambridge University Press. Greville, Fulke. (1870). The Tragedy of Prince Mustapha (1603). London, Lancaster.

Gruber, Christiane J. (2010), The Prophet's Ascension: cross-cultural encounters with the Islamic mi'räj tales, Christiane J. Gruber, Frederick Stephen Colby (eds), Indiana University Press.

Gruber, Christiane J. (2013). Images of the Prophet In and Out of Modernity: The Curious Case of a 2008 Mural in Tehran, in Christiane Gruber; Sune Haugbolle (17 July 2013). Visual Culture in the Modern Middle East: Rhetoric of the Image. Indiana University Press.

Hakluyt, Richard. (1600). The Principall Navigations, Voiages, Traffiques and Discoueries of the English Nation. London, G. Bishop.

Higden, Ranulph. (1527). Polychronycon. London, John Reynes.

http://quod.lib.umich.edu/e/eebo/A67922.0001.001?rgn=full+text;view=toc;q1=Polychronycon

Ibn Katheer, A. (1999). Tafsir Ibn Kathir (Great interpretation of the Qur'an). Vol, 1. Damascus, Dar Taibah.

Kidwai, A.R. (1997). The Crescent and The Cross: Image of the Orient in English Literature Up to 1832. Aligarh, Aligarh Muslim University Press.

Knolles, Richard, $(1603,1701)$ The Generall Historie of the Turkes, London, Adam Islip.

Loomba, Ania \& Burton, Jonathan (2007) Race in Early Modern England: A Documentary Companion. New York, Palgrave Macmillan

McJannet, L. (2006). The Sultan Speaks: Dialogue in English Plays and Histories about Ottoman Turks Basingstoke, Palgrave Macmillan

MacLean, Gerald (2007). Looking East: English Writing and the Ottoman Empire before 1800. Hampshire, Palgrave Macmillan.

MacLean, G. and Matar, Nabil. (2010). Britain and the Islamic World, 1558-1713. Oxford, University Press.

Mandeville, Sir John. (1982). The Travels of Sir John Mandeville. trans. C.W.R.D. Moseley. London, Penguin Book. Matar, Nabil. (1991)."Islam in Interregnum and Restoration England," The Seventeenth Century vol.6, no. 1 (1991); pp. 67-87.

Matar, Nabil. (1998). Islam in Britain 1558-1685. Cambridge, Cambridge University Press.

Matar, Nabil. (1999). Turks, Moors, and Englishmen in the Age of Discovery. New York, Columbia University Press. 
Matar, Nabil. \& Stoeckel, Rudolph. (2004). 'Europe's Mediterranean Frontier: The Moor', pp. 220-52 in Andrew Hadfield and Paul Hammond (eds), Shakespeare and Renaissance Europe. London, Arden Critical Companions.

Munro, Dana C. (1931). "The Western Attitude toward Islam during the Period of the Crusades," Speculum vol.6, no. 3 (1931): pp. 331-342.

Munster, Sebastian. (1574). A Brief Collection and compendious extract of straunge and memorable Thinges. London,

TomasMarshe.http://quod.lib.umich.edu/e/eebo/A07871.0001.001?cite1=Munster\%2C+Sebastian.;cite1restrict =author;rgn=full+text;view=toc; 1 =memorable+Thinges

Oueijan, Naji B. (1966). The Progress of an Image: The East in English Literature. New York, Peter Lang.

Pearsall, Derek. (1978). (ed.), William Langland's Piers Plowman. London, Edward Arnold.

Poole, Stanley Lane. (1882). Table Talk of the Prophet Muhammad. London, Macmillan.

Ramadan, Tariq (2007). The Messenger: The Meanings of the Life of Muhammad. London, Allen Lane.

Reeves, Minou. (2000). Muhammad in Europe: A Thousand Years of Western Myth-Making. New York, New York University Press.

Schmuck, Stephan. (2010). “England's Experiences of Islam” in M. Hattaway (ed.) A New Companion to English Renaissance Literature and Culture. London, Oxford

Selden, John. (1992). Table Talk, or the Discourses of John Selden, in Kenneth Setton, Western Hostility to Islam and Prophecies of Turkish Doom. Philadelphia, PA: American Philosophical Society.

Southern, R.W. (1962). Western Views of Islam in the Middle Ages. Cambridge, MASS, Harvard University Press. Tyndale, William, (1940). An Answere vnto Sir Thomas Mores Dialoge (1531) ed. Henry Walter Cambridge, Cambridge University Press.

Tolan, John. (ed.) (2000). Medieval Christian Perceptions of Islam. Routledge. Chapman.

Tolan, John. (2002). Saracens: Islam in the Medieval European Imagination. New York, Columbia University Press.

Vitkus, Daniel. (1997). "Turning Turk in Othello: The Conversion and Damnation of the Moor" Shakespeare Quarterly, Vol. 48, No. 2 (Summer, 1997), pp. 145-176.

Vitkus, Daniel J. (1999). “Early Modern Orientalism: Representations of Islam in Sixteenth- and SeventeenthCentury Europe," in David R. Blanks and Michael Frassetto, (ed.) Western Views of Islam in Mediaeval an Early Modern Europe: Perception of Other, New York, St. Martin's Press.

Vitkus, Daniel J. (2000). Three Turk Plays from Early Modern England. New York, Columbia University Press.

Vitkus, Daniel J. (2003). Turning Turk: English Theater and the Multicultural Mediterranean, 1570-1630. New York, Palgrave Macmillan.

Wann, Louis (1915) “The Oriental in Elizabethan Drama”. Modern Philology. vol.12, pp.423-447.

Watt, William Montgomery (1991). Muslim-Christian Encounters: Perceptions and Misperceptions. London and New York, Routledge.

Westermarck, Edward.(1933).Pagan Survivals in Mohammedan Civilization. London, Macmillan.

Wolf, C. Umhau. (1941). "Luther and Mohammedanism" The Moslem World. vol.31 (1941) pp.161-177.

Zimmerman, Seth. (2003). The Inferno of Dante Alighieri. iUniverse. 